\title{
Efficacy, timing and method of application of fungicides for management of sorghum ergot caused by Claviceps africana
}

\author{
Malcolm Ryley $^{\mathrm{A}, \mathrm{D}}$, Shamsul Bhuiyan ${ }^{\mathrm{B}}$, Damian Herde ${ }^{\mathrm{A}}$ and Bill Gordan ${ }^{\mathrm{C}}$

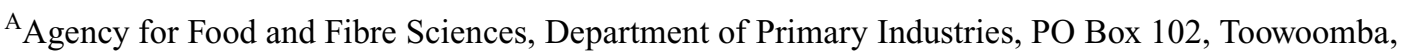 \\ Qld 4350, Australia. \\ ${ }^{B}$ Formerly School of Agriculture and Horticulture, The University of Queensland, Gatton Campus, Gatton, Qld \\ 4343, Australia; current address: Australian Quarantine and Inspection Service, Fisherman Island, \\ Qld 4178, Australia. \\ ${ }^{\mathrm{C}}$ Formerly Agency for Food and Fibre Sciences, Department of Primary Industries, PO Box 102, Toowoomba, Qld \\ 4350, Australia; current address: Centre for Pesticide Application Systems, The University of Queensland, Gatton \\ Campus, Gatton, Qld 4343, Australia. \\ ${ }^{\mathrm{D}}$ Corresponding author; email: Malcolm.Ryley@dpi.qld.gov.au
}

\begin{abstract}
Trials conducted in Queensland, Australia between 1997 and 2002 demonstrated that fungicides belonging to the triazole group were the most effective in minimising the severity of infection of sorghum by Claviceps africana, the causal agent of sorghum ergot. Triadimenol (as Bayfidan 250EC) at $0.125 \mathrm{~kg}$ a.i./ha was the most effective fungicide. A combination of the systemic activated resistance compound acibenzolar-S-methyl (as Bion 50WG) at $0.05 \mathrm{~kg}$ a.i./ha and mancozeb (as Penncozeb $750 \mathrm{DF}$ ) at $1.5 \mathrm{~kg}$ a.i./ha has the potential to provide protection against the pathogen, should triazole-resistant isolates be detected. Timing and method of fungicide application are important. Our results suggest that the triazole fungicides have no systemic activity in sorghum panicles, necessitating the need for multiple applications from first anthesis to the end of flowering, whereas acibenzolar-S-methyl is most effective when applied 4 days before flowering. The flat fan nozzles tested in the trials provided higher levels of protection against $C$. africana and greater droplet deposition on panicles than the tested hollow cone nozzles. Application of triadimenol by a fixed wing aircraft was as efficacious as application through a tractor-mounted boom spray.
\end{abstract}

Additional keywords: triadimenol, acibenzolar-S-methyl, nozzles.

\section{Introduction}

Sorghum ergot is caused by Claviceps africana, C. sorghi (Bandyopadhyay et al. 1996) and C. sorghicola (Tsukiboshi et al. 1999). The anamorph of the three species is considered to be Sphacelia sorghi (Bandyopadhyay et al. 1998). C. africana has in recent years spread from Africa and Asia to the Americas and Australia (Bandyopadhyay et al. 1998), whereas $C$. sorghi is restricted to the Indian subcontinent, and C. sorghicola to Japan (Bandyopadhyay et al. 1998; Tsukiboshi 1999). Sorghum ergot is a localised disease of unfertilised florets where the ovary is replaced with a fungal mass (the sphacelium) on which macroconidia are produced. The macroconidia are released into honeydew which oozes from the infected spikelets and, for C. africana, macroconidia near the surface of the honeydew germinate producing a short sterigma on which a single secondary conidium develops. Airborne secondary conidia are believed to be the major infective propagules of $C$. africana (Frederickson et al. 1993). In contrast, secondary conidia have not been reported in nature for either $C$. sorghi or C. sorghicola (Frederickson et al. 1991; Tsukiboshi et al.
1999). Later, sclerotia may develop from the sphacelial tissue (Frederickson and Odvody 1999). Mature sclerotia of C. sorghi and C. sorghicola readily germinate (Bandyopadhyay et al. 1998; Tsukiboshi et al. 1999), but germination of C. africana sclerotia is poor (Frederickson et al. 1991). Sclerotia of the latter species appear to have little or no role in the survival of the pathogen and, in Australia, C. africana can survive year-round on alternative and volunteer hosts (Ryley et al. 2003a) and, for a limited period, on infected panicles (Bhuiyan et al. 2002).

Fertilised florets are considered to be resistant to infection by $C$. africana, so any reduction in the availability of viable pollen has a significant effect on ergot outbreaks (McLaren and Wehner 1990, 1992). Male sterile lines (A-lines) used in the production of F1 hybrid seed of Sorghum bicolor and in breeders' nurseries and seed increase blocks are, therefore, at considerable risk. Although relative differences in resistance to C. africana in A-lines have been identified (Dahlberg et al. 2001), none with high levels of resistance have been found. Strategies recommended for hybrid seed production include applications of fungicides, an increase in the ratio of 
pollen donor (B- or R-) lines:A-lines, and planting at times or localities to reduce the likelihood of exposure to high inoculum levels (Bandyopadhyay et al. 1996). Non-synchronisation of flowering periods between the A-lines and B- or R-lines, caused by abiotic or biotic factors, can have a significant impact on ergot severity in these situations. Fungicides have been used to reduce ergot infection levels in sorghum for many years in India, but the outbreak of ergot in the hybrid seed production plots in South America has stimulated considerable research in the newer fungicide groups.

In India, Anahosaur (1980) found that the dithiocarbamate, mancozeb, was the most effective fungicide in reducing ergot severity and increasing yield. Other fungicides reported to be efficacious in India and Zimbabwe were the methyl benzimidazole carbamates, carbendazim (Lakshmanan and Mohan 1988), thiophanatemethyl (Lakshmanan et al. 1986) and benomyl (McLaren 1994; Frederickson and Leuschner 1997), the dithiocarbamate, thiram (Frederickson and Leuschner 1997), and the phthalimide, captafol (Lakshmanan et al. 1986). C. sorghi was assumed to be the only Claviceps species on Sorghum in India, but recent findings (Pazoutova et al. 2000) demonstrate that $C$. africana may have coexisted with C. sorghi for some years. Consequently, there is some uncertainty regarding the identity of the Claviceps species in Indian reports of fungicide efficacy. The triazoles have been demonstrated to provide even higher levels of protection against C. africana in South America (Mena et al. 1998; Pinto et al. 1999) and Africa (McLaren 1994).

Multiple applications of fungicides, including the triazoles, are necessary for a significant reduction in ergot incidence and severity (Anahosaur 1980; Lakshmanan et al. 1986; Lakshmanan and Mohan 1988; McLaren 1994; Mena et al. 1998). This is undoubtedly related to the fact that flowering of the florets in a single panicle proceeds from top to bottom, and may extend over a period of 6-15 days, depending on the genotype and weather factors (Doggett 1988). Timing of spraying is critical in ergot management. A single application of an efficacious fungicide was most effective when applied at flowering, with ergot severity increasing when applied before (McLaren 1994) or after (McLaren 1994; Frederickson and Leuchner 1997; Odvody 2001) this time. McLaren (1994) surmised that the triazoles propiconazole and triadimenol had limited curative activity and that systemic movement of the chemicals towards the infection court was limited.

In most trials from which fungicide efficacy data have been generated, the fungicides have been applied using either backpack sprayers (McLaren 1994; Mena et al. 1998) or hand sprayers (Odvody 2001). No details of the nozzles or the water application rates were provided in any of these reports. No published reports on efficacy of fungicides applied by aircraft are available.
In Australia, the greatest impacts of C. africana have been on the production of parent and hybrid seed, the maintenance of important germplasm and the threat of livestock toxicity (Ryley et al. 2003b). It has been estimated that the management of sorghum ergot has imposed an increase in the cost of production of AUD $\$ 20$ per $25 \mathrm{~kg}$ bag (B. Boucher, personal communication). Therefore, in order to develop cost-effective management of sorghum ergot in seed production situations, trials were conducted between 1997 and 2002 in Queensland to determine the effects of different rates, timing and intervals, and application methods of chemicals on infection by Australian isolates of C. africana.

\section{Methods}

Field trials were conducted in southern Queensland at Pacific Seeds Research Station, Lawes $\left(27^{\circ} 32^{\prime} \mathrm{S} 152^{\circ} 19^{\prime} \mathrm{E}\right)$, Grantham $27^{\circ} 32^{\prime} \mathrm{S}$ $152^{\circ} 12^{\prime} \mathrm{E}$ ), and in north Queensland at the Department of Primary Industries Ayr Research Station, Ayr (20 $\left.366^{\prime} \mathrm{S} 146^{\circ} 10^{\prime} \mathrm{E}\right)$, and one glasshouse trial at the University of Queensland, Gatton Campus $\left(27^{\circ} 32^{\prime} \mathrm{S} 152^{\circ} 20^{\prime} \mathrm{E}\right)$. Unless otherwise described, all field trials were of a randomised complete block design. The following fungicides were used in one or more of the trials: (i) the demethylation inhibitors (DMI) (triazole chemical group), triadimenol (Bayfidan 250EC $250 \mathrm{~g} / \mathrm{L}$, Bayer CropScience Australia), tebuconazole (Folicur 430EC $430 \mathrm{~g} / \mathrm{L}$, Bayer CropScience Australia), propiconazole (Tilt 250EC, $250 \mathrm{~g} / \mathrm{L}$, Novartis), unknown triazole (JAU6476, 250 g/L, CropCare Australasia); (ii) the dicarboximide, procymidone (Sumisclex 275 Flocol $275 \mathrm{~g} / \mathrm{L}$, CropCare Australasia); (iii) the amine (morpholine chemical group), tridemorph (Calixin $750 \mathrm{EC} 750 \mathrm{~g} / \mathrm{L}, \mathrm{BASF}$ ); (iv) the 2,6-dinitroaniline, fluazinam (Shirlan 500SC $500 \mathrm{~g} / \mathrm{L}$, CropCare Australasia); (v) the quinone outside inhibitor (methoxyacrylate chemical group), azoxystrobin (Amistar 500WG $500 \mathrm{~g} / \mathrm{L}$, CropCare Australasia); (vi) the dithiocarbamate (chemical group), mancozeb (Penncozeb 750DF, $750 \mathrm{~g} / \mathrm{L}$ Nufarm); (vii) the methyl benzimidazole carbamate (benzimidazole chemical group) benomyl (Benlate WP $500 \mathrm{~g} / \mathrm{L}$, DuPont); (viii) the hydroxyanilide, fenhexamid (Teldor 500SC $500 \mathrm{~g} / \mathrm{L}$, Bayer CropScience Australia); and (ix) the P1 host plant defence inducer (benzo-thiadiazole chemical group), acibenzolarS-methyl (Bion 50WG $50 \mathrm{~g} / \mathrm{L}$, Syngenta) (classification after www.frac.info/ publications/chemical\%20group.html).

In all but four trials (application trials 2, 4 and 5, and the glasshouse timing trial), the chemicals were applied using a hand-held boom sprayer through various types of nozzles, with one nozzle directly above the panicle, and one on either side of the panicle on droppers and facing towards the panicle. Pressure was supplied using bottled propane gas. Spraymate Bond (Nufarm) was added to all fungicides at $0.1 \%$, except for the aerial application trial and the glasshouse timing trial.

In most trials (apart from application trials 4 and 5), all rows were inoculated on one occasion with a suspension of approximately $10^{6}$ conidia/mL water (= standard conidium suspension) applied through a backpack sprayer until droplets were observed on the panicles. The conidial suspensions were produced by excising sorghum panicles with copious honeydew from other trials at the DPI Gatton Research Station, Gatton, and agitating them in a container containing water. After an initial calibration between the optical density of the suspension and conidial concentration using a haemocytometer, subsequent suspensions were adjusted using optical density as the measurement.

All data were arcsine transformed before ANOVA or other analysis using the statistical packages Genstat v3 or 5 (Lawes Agricultural Trust, Rothamsted Experimental Station) or SAS (SAS Institute v6.12, Cary NC, USA). 
Table 1. Fungicides and compounds used in efficacy trials against Claviceps africana

\begin{tabular}{lccccc}
\hline Fungicide/compound & \multicolumn{2}{c}{ Rate } & \multicolumn{4}{c}{ Trial number } \\
& (kg a.i./ha) & 1 & 2 & 3 & 4 \\
\hline Triadimenol & 0.063 & & $\mathrm{X}^{\mathrm{A}}$ & $\mathrm{X}$ & \\
Triadimenol & 0.125 & $\mathrm{X}$ & $\mathrm{X}$ & $\mathrm{X}$ & $\mathrm{X}$ \\
Triadimenol & 0.25 & $\mathrm{X}$ & & & \\
Acibenzolar-S-methyl & 0.025 & & $\mathrm{X}$ & & \\
Acibenzolar-S-methyl & 0.05 & & $\mathrm{X}$ & $\mathrm{X}$ \\
Acibenzolar-S-methyl + mancozeb & $0.05+1.50$ & & $\mathrm{X}$ & $\mathrm{X}$ \\
Propiconazole & 0.125 & & $\mathrm{X}$ & & \\
Propiconazole & 0.25 & & $\mathrm{X}$ & & \\
Tebuconazole & 0.25 & $\mathrm{X}$ & $\mathrm{X}$ & & \\
Procymidone & 0.125 & $\mathrm{X}$ & & & \\
Procymidone & 0.25 & $\mathrm{X}$ & & & \\
Triademorph & 0.30 & $\mathrm{X}$ & & & \\
Fluazinam & 0.25 & $\mathrm{X}$ & & & \\
Fluazinam & 0.50 & $\mathrm{X}$ & & & \\
Azoxystrobin & 0.063 & & $\mathrm{X}$ & & \\
Azoxystrobin & 0.125 & & $\mathrm{X}$ & & \\
Mancozeb & 1.50 & $\mathrm{X}$ & $\mathrm{X}$ & & \\
Benomyl & 1.00 & $\mathrm{X}$ & & & \\
Fenhexamid & 0.25 & & & & $\mathrm{X}$ \\
Fenhexamid & 0.50 & & & & $\mathrm{X}$ \\
? (JAU4676) & 0.125 & & & & $\mathrm{X}$ \\
? (JAU4676) & 0.25 & & & & $\mathrm{X}$ \\
\hline A & & & & &
\end{tabular}

${ }^{\mathrm{A}}$ Fungicide/compound tested.

\section{Efficacy}

Four efficacy trials were conducted in southern Queensland to compare the efficacy of various fungicides and compounds (Table 1). Details of the trials are presented in Table 2. In efficacy trials 1 and 2, a mixture of two Pacific Seeds proprietary A-lines (PAC 71035 and
PAC 71171) were used to lengthen the flowering period, thereby enabling evaluation of the fungicides and compounds over a longer-than-normal flowering period. In trial 3, each plot consisted of eight rows of an A-line mix (PAC 71035 and PAC 71189), with two rows of an R-line mix (PAC 91419 and PAC 91310) on each side, simulating a hybrid seed production block. In trial 4, the A-line AQL 03275 was used.

Hollow cone Teejet TX4 nozzles were used in the first three trials, but flat fan Teejet TX110011VB nozzles (Farming Systems Co., USA) were used in the last trial. In trial 2, all fungicide treatments except the acibenzolar-S-methyl + mancozeb combination were applied eight times, at 4- to 5-day intervals; for that treatment acibenzolar-S-methyl was applied once at first anthesis, then mancozeb was applied seven times, at 4- to 5-day intervals. In trial 3, two rates of triadimenol were applied four times at 4-day intervals, the acibenzolar-S-methyl only treatment was applied once, 4 days before anthesis, and for the acibenzolar-S-methyl + mancozeb treatment the former compound was applied 4 days before anthesis, and mancozeb every $4-5$ days thereafter, for a total of four sprays.

All rows were inoculated either immediately after (trials $1,2,3$ ) or 9 days after (trial 4), the first fungicide spray (Table 2). Two to 4 weeks after the last spray, the severity (per cent infected spikelets/panicle) was assessed for every panicle in the datum rows and the mean values of severity and incidence (per cent infected panicles/row) were calculated.

\section{Spray interval/timing}

Three trials with different spray intervals of timing of applications were conducted. Interval trial 1 was designed to determine the optimum spray interval for tebuconazole, and interval trial 2 to determine the relationship between the number of sprays of acibenzolar-S-methyl and efficacy. The chemicals in both trials were applied with three TX4 hollow cone nozzles in either $200 \mathrm{~L}$ water/ha (trial 1) or $230 \mathrm{~L}$ water/ha (trial 2). Pressure was supplied by propane gas at $450 \mathrm{kPa}$ in trial 1 and at $400 \mathrm{kPa}$ in trial 2 . In both trials, a standard conidial suspension was applied to all rows at first anthesis with a backpack sprayer within $1 \mathrm{~h}$ of the first fungicide spray. The third trial, conducted on plants growing in a glasshouse at the University of Queensland, Gatton Campus,

Table 2. Details of chemical efficacy trials against Claviceps africana

\begin{tabular}{lcccc}
\hline & Trial 1 & Trial 2 & Trial 3 & Trial 4 \\
\hline Location & Lawes & Lawes & Lawes & Grantham \\
Planting date & $15 / 2 / 1997$ & $18 / 2 / 1998$ & $? / 2 / 1999$ & $? / 2 / 2001$ \\
Genotype & A-line mix $^{\mathrm{A}}$ & A-line mix $^{\mathrm{A}}$ & A-line mix $^{\mathrm{B}}+\mathrm{R}$-line mix $^{\mathrm{C}}$ & AQL 03275 \\
Flowering period (days) & 22 & 22 & 14 & 14 \\
Plot size (no. rows $\times$ length) & $3(1)^{\mathrm{D}} \times 7 \mathrm{~m}$ & $3(1) \times 8 \mathrm{~m}$ & A-line $8(6) \times 9 \mathrm{~m}+\mathrm{R}-$ line $2 \times 9 \mathrm{~m}^{\mathrm{E}}$ & $4(2) \times 6 \mathrm{~m}$ \\
Replicates & 4 & 4 & 6 & 4 \\
Nozzles & $3 \times \mathrm{TX} 4$ & $3 \times \mathrm{TX} 4$ & $3 \times \mathrm{TX} 4$ & $3 \times$ TX11001VB \\
Spray rate (L/ha) & 200 & 230 & 250 & 230 \\
Spray pressure (kPa) & 400 & 400 & 450 & 200 \\
Spray start & $10 / 4 / 1997$ & $3 / 4 / 1998$ & $17 / 4 / 1999$ & $12 / 4 / 2001$ \\
Spray number & 7 & $8^{\mathrm{F}}$ & 4 or $1^{\mathrm{G}}$ & 4 \\
Spray interval (days) & $6 \times 4 \mathrm{~d}, 1 \times 6 \mathrm{~d}$ & $4-5 \mathrm{~d}$ & 4,0 or $4-5 \mathrm{~d}^{\mathrm{G}}$ & $4-5$ \\
Inoculation date & $10 / 4 / 1997$ & $3 / 4 / 1998$ & $17 / 4 / 1999$ & $21 / 4 / 2001$ \\
Rating dates & $29 / 5 / 1997 \& 6 / 6 / 1997$ & $20 / 5 / 1998$ & $15 / 5 / 1999$ & $20 / 5 / 2001$ \\
\hline
\end{tabular}

${ }^{\mathrm{A} A}$-lines PAC $71035+$ PAC 71171. ${ }^{\mathrm{B} A-l i n e s}$ PAC $71035+$ PAC $71189 . \quad{ }^{\mathrm{C}} \mathrm{R}$-lines PAC $91419+$ PAC 91310.

${ }^{\mathrm{D}}$ Figure in parenthesis is the number of datum rows.

${ }^{\mathrm{E}}$ Eight rows of A-line mix, with two rows of R-line mix on each side of A-line rows.

${ }^{F}$ All treatments were applied eight times; in the acibenzolar-S-methyl + mancozeb treatment the former was applied once, followed by seven sprays of mancozeb.

${ }^{\mathrm{G}}$ The two triadimenol treatments were applied four times at 4-day intervals, the acibenzolar-S- methyl treatment was applied once, and in the acibenzolar-S-methyl + mancozeb treatment the former was applied once, followed by three sprays of mancozeb at 4- to 5-day intervals. 
evaluated the influence of the timing of a single application of triadimenol or acibenzolar-S-methyl on ergot severity.

Interval trial 1. A mixture of Pacific Seeds propriety A-lines (PAC 71035 and PAC 71171), with a flowering period of approximately 30 days, was planted at Lawes on 17 February 1997. Plots consisted of three 9-m long rows, with rows $70 \mathrm{~cm}$ apart and the centre row as datum; there were six replicates. Tebuconazole at $250 \mathrm{~g}$ a.i./200 L water/ha was applied to all three rows in each plot except the unsprayed treatment at first anthesis (2 April 1997), then at 2-, 4-, 6-, or 8-day intervals for a total of 16, eight, six, or four sprays, respectively. On 29 May 1997 ergot severity was visually assessed on each panicle in the datum rows using the following scale: $0=0 \%$ infected spikelets, $1=$ $0-1 \%, 2=2-5 \%, 3=6-10 \%, 4=11-20 \%, 5=21-35 \%, 6=36-50 \%$, $7=51-75 \%, 8=76-90 \%, 9=91-99 \%, 10=100 \%$, and the mean incidence $(\%=$ number infected panicles $\times 100 /$ total number panicles $)$ and mean severity were calculated for each treatment.

Interval trial 2. A mixture of two A-lines (AQL 03275 and an unknown Pioneer proprietary line) with a flowering period of approximately 27 days was planted at Grantham on 16 February 1998. Each plot consisted of one 8-m long row; plots were $75 \mathrm{~cm}$ apart and there were four replicates of 12 treatments, including an unsprayed control. Propiconazole at 0.125 or $0.25 \mathrm{~kg}$ a.i./ha, tebuconazole at 0.25 $\mathrm{kg}$ a.i./ha and triadimenol at 0.063 or $0.125 \mathrm{~kg}$ a.i./ha were applied eight times, at 4-day intervals. Acibenzolar-S-methyl at 0.025 or $0.05 \mathrm{~kg}$ a.i./ha was applied once, twice (at 16-day intervals) or four times (at 8 -day intervals). The first sprays of all treatments were applied at first anthesis (17 April 1998). On 1 June 1998, ergot severity was visually assessed on each panicle in the datum rows using the same scale as in interval trial 1. Mean ergot incidence and mean severity were calculated for each treatment.

Timing trial. A glasshouse experiment was conducted to determine the effect of the timing of application of either triadimenol at $0.125 \mathrm{~kg}$ a.i./ha or acibenzolar-S-methyl at $0.05 \mathrm{~kg}$ a.i./ha on ergot severity. Plants of a Pacific Seeds A-line PAC 71077 were grown in sterile potting mix (pine bark: sawdust: sand, 2:2:1) in 20-cm-diameter pots in a glasshouse and watered and fertilised at regular intervals. At $50 \%$ anthesis, the upper portions of the panicle with spikelets that had flowered (withered filaments and anthers) and the lower portions with spikelets that had not yet flowered were excised, leaving the central portion with spikelets containing bright yellow anthers. Both fungicides were applied separately, using a hand sprayer, to individual panicles until runoff with different timing regimes; that is, 7 or 4 days before, within $30 \mathrm{~min}$ after, and 2 or 4 days after, inoculation. There were six plants in each treatment and the plants were returned to the glasshouse after spraying. All panicles were inoculated to runoff on the same day with a standard conidial suspension using a hand sprayer, and each was then covered with a paper bag. Six panicles that had not been sprayed with either chemical served as controls. The plants were returned to the glasshouse and the bags removed 1 day later. Fifteen days after inoculation, each panicle was visually assessed for per cent infected spikelets (= severity) and the mean ergot severity was calculated.

\section{Application methods}

Five trials to investigate different application methods of triadimenol were conducted, three field trials in southern Queensland and two in north Queensland. In the first two trials, the efficacy of several flat fan nozzles was compared with hollow cone nozzles, while in trial 3 application using a low water rate $(50 \mathrm{~L} / \mathrm{ha})$ was compared with a high rate $(250 \mathrm{~L} / \mathrm{ha})$. In trials 4 and 5 , the efficacy of triadimenol applied in $50 \mathrm{~L}$ water/ha with a fixed-wing aircraft was compared with application in $150 \mathrm{~L}$ water/ha using a tractor-mounted boom spray.

Trial 1. This trial, conducted at Grantham on a mixture of AQL 03275 and a Pioneer proprietary A-line resulting in a flowering period of approximately 27 days, was planted in mid-February 1999. There were seven treatments (including an unsprayed control) with five replicates and plots consisted of four $5-\mathrm{m}$ long rows, $75 \mathrm{~cm}$ apart. All rows in the fungicide treatments were sprayed where appropriate, but only $4 \mathrm{~m}$ of the middle two rows were used as datum rows. Triademenol was applied at $0.063 \mathrm{~kg}$ a.i. $/$ ha using TX11001VB flat fan nozzles, TJ60 twin flat fan nozzles, TX2 hollow cone nozzles, or TX4 hollow cone nozzles (all Teejet; Spraying Systems Co., USA). For the TX11001VB and TX4 nozzles, plots were sprayed either in a single direction or from both directions, while for the TJ60 and TX 2 nozzles only a single direction spray was applied. A pressure of $200 \mathrm{kPa}$ was used for the hollow cone nozzles and $450 \mathrm{kPa}$ for the flat fan nozzles. Walking speed was calibrated to ensure an application of $250 \mathrm{~L}$ water/ha for each treatment. The first spray was applied at first anthesis (4 May 1999), then at 4-day intervals for a total of eight sprays. All rows were inoculated on 6 May 1999 using a standard conidial suspension. On the first spray date the fluorescent dye Helios 500SC (Ciba-Geigy, Basel, Switzerland) was added to the fungicide solution at $30 \mathrm{~g}$ a.i./ha and, immediately after spraying, random samples of ten panicles per plot were collected and placed in separate paper bags. The droplet distribution on each panicle was assessed visually with the aid of a UV light, as (a) evenness of vertical coverage (top to bottom of panicle) on a 1-5 scale with $1=$ very uneven and 5 = very even, (b) evenness of horizontal coverage (around the panicle) on a $1-5$ scale with $1=$ very uneven and 5 = very even, (c) evenness of droplet size on a $0-1$ scale. Droplet coverage was calculated as the product of the three parameters. On 20 June 1999, per cent infected spikelets/panicle was estimated on 20 randomly selected panicles/datum row.

Trial 2. The trial was conducted at Lawes, using plots of six $12-\mathrm{m}$ long rows of a proprietary Pacific Seeds A-line, with two $12 \mathrm{~m}$ rows of an R-line on each side; the datum rows were the middle four A-line rows. There were four nozzle treatments and an unsprayed control in five replicates. Triadimenol was applied four times at 4-day intervals, the first $(0.1 \mathrm{~kg}$ a.i./ha) at first anthesis (5 April 2000) and the remainder at $0.063 \mathrm{~kg}$ a.i./ha, for all nozzle treatments. Helios was added at $30 \mathrm{~g}$ a.i./ha to all sprays before application. The nozzles tested were 30H-CX4 hollow cones (Lurmark Limited, Longstanton, Cambridge, UK) at $500 \mathrm{kPa}$ that produced a very fine droplet (BCPC droplet classification), and the flat fans XR $80^{\circ}-01$ at $500 \mathrm{kPa}$ (fine/very fine) or $700 \mathrm{kPa}$ (very fine) and DG80 -015 (fine/medium) at $500 \mathrm{kPa}$ (both Teejet; Spraying Systems Co., USA). The fungicide was applied with a purpose-built, high clearance, self-propelled spray rig with 24 nozzles arranged in eight groups of three (one above the panicles and two on droppers) and ground speed was adjusted to ensure that $300 \mathrm{~L}$ water/ha was applied to all plots. All rows were inoculated with a standard conidial suspension on 9 April 2000.

Prior to the first application, four $30-\mathrm{cm}$-long pipe cleaners were attached, at $90^{\circ}$ to each other and bent so they were vertical and approximately $6 \mathrm{~cm}$ from the panicle, to each of four panicles per plot. After the first spray, all pipe cleaners and random samples of four panicles per plot were collected and placed in paper bags. The pipe cleaners were washed in $10 \mathrm{~mL}$ of ethyl digol solvent to extract the florescent pigment. The solution was filtered and the quantity of Helios in the filtrate was measured using a Sequoila-Turner fluorometer. The total amount of dye deposited on the panicles was expressed as a standardised unit $(\mu \mathrm{g} / \mathrm{L}$ of Helios $/ 10 \mathrm{~mL}$ solvent/g panicle). The selected panicles were washed in $30 \mathrm{~mL}$ of ethyl digol and the filtrate treated as above. The total amount of dye deposited on the panicles was expressed as a standardised unit $(\mu \mathrm{g} / \mathrm{L}$ of Helios $/ 30 \mathrm{~mL}$ solvent $/ \mathrm{g}$ panicle). Severity (as per cent infected spikelets/panicle) was visually assessed on 20 randomly selected panicles in each A-line datum row on 5 May 2000.

Trial 3. This trial was conducted at Pacific Seeds Research Station, Lawes, to determine the relative efficacy of applying triadimenol at $0.125 \mathrm{~kg}$ a.i./ha in only $50 \mathrm{~L}$ water, through hollow cone nozzles. The fungicide was applied with two TX2 hollow cone nozzles one each on 
a dropper and held $40-50 \mathrm{~cm}$ above the row. Two other treatments, triadimenol applied at $0.125 \mathrm{~kg}$ and $0.25 \mathrm{~kg}$ a.i. $/ 250 \mathrm{~L}$ water/ha through three TX11001VB flat fan nozzles per row, were included. The fungicide was applied through the hollow cone nozzles at $400 \mathrm{kPa}$, and through the flat fan nozzles at $200 \mathrm{kPa}$. Plots consisted of six rows $5 \mathrm{~m}$ long of an unknown A-line with the middle four as datum rows, with two rows of an unknown R-line on each side; there were four replicates. Triadimenol was applied through the hollow cone nozzles once, twice or four times. The single application was on 5 May 2002, the two applications on 5 and 9 May 2002, and the four applications at 4-day intervals beginning 1 May 2002 (at first anthesis). Both flat fan treatments were applied four times on the same days as the four hollow cone treatments. All rows were inoculated with a standard conidial suspension using a backpack sprayer on 5 May 2002, 30 min after the fungicides were applied. The incidence and severity of ergot were assessed in each row on 4 June 2002.

Trials 4 and 5. These trials, conducted at the QDPI Research Station near Ayr, north Queensland, during the winter of 2002, were used to determine the relative efficacy of triadimenol applied by a fixed-wing aircraft compared with applications by a ground rig. Pioneer proprietary A-lines and R-lines were used in these trials that were planted on 13 June 2002. Neither trial was inoculated.

In the aerial application trial, there were two blocks, the sprayed block consisting of alternate plots of two 120-m long rows of R-lines and six $120-\mathrm{m}$ long rows of A-lines for a total of 42 rows, and the unsprayed blocks consisting of a similar arrangement of A- and R-lines, all $80 \mathrm{~m}$ long. Row spacing was $0.70 \mathrm{~m}$ and data were collected from the middle four rows of the A-line plots. Triadimenol at $0.125 \mathrm{~kg}$ a.i./ ha was applied on 2, 6 and 10 September 2002 for a total of three sprays. The fungicide was applied in $50 \mathrm{~L}$ water/ha at $372 \mathrm{kPa}$, using CP-03-3 nozzles (The CP Products Co., Inc., Tempe, AZ, USA) with a $90^{\circ}$ shear plate.

The ground rig trial was conducted upwind from the aerial application trial and was separated from it by 150 rows (approximately $100 \mathrm{~m}$ ) of bulk sorghum. There were two blocks, in each of which were three replicates of three completely randomised treatments, with each plot consisting of six 20-m long rows of A-line with two 20-m long rows R-line on both sides; rows were $0.75 \mathrm{~m}$ apart. The blocks were separated by ten rows of bulk sorghum. Triadimenol was applied at either 0.125 or $0.25 \mathrm{~kg}$ a.i./100 L water/ha on 2, 6, 10 and 15 September 2002 using a tractor-mounted, hydraulic boom spray with Conejet IXVK-8 hollow cone nozzles (Spraying Systems Co., USA) spaced at $0.75 \mathrm{~m}$ and at a pressure of $517 \mathrm{kPa}$.

In the aerial application trial, severity was visually assessed as per cent infected spikelets/panicle on 24 random samples each of 20 panicles across the blocks, and in the ground rig trial on four samples each of 20 panicles/treatment/block/replicate on 8 or 9 October 2002. All data were arcsine transformed before analyses; data from the aerial application trial were analysed using Student's ' $t$ ' test, and data from the ground rig trial were analysed using an Analysis of Variance with the Genstat v5 (release 4.21) statistical package (Lawes Agricultural Trust, Rothamsted Experimental Station).

\section{Results}

Reference to statistically significant differences in parameters between treatments is at $P<0.05$, unless otherwise stated.

\section{Efficacy}

Trial 1. On the first rating date, seven treatments had significantly lower ergot incidence values than the unsprayed treatment and six of these had significantly lower values of severity (Table 3 ). The best three treatments (triadimenol at
$0.25 \mathrm{~kg}$ or $0.125 \mathrm{a}$.i./ha, and tebuconazole at $0.25 \mathrm{~kg}$ a.i./ha) were not significantly different from each other with respect to per cent incidence and, for severity, the differences between the six best treatments were not statistically significant. On the second rating date, the two triadimenol treatments and the tebuconazole treatment had significantly lower per cent incidence values than the remainder and, although severity data were not analysed, only these three treatments had a severity range of $0-1 \%$.

Trial 2. All fungicide $\times$ compound treatments except azoxystrobin at $0.063 \mathrm{~kg}$ a.i.ha, tebuconazole at $0.25 \mathrm{~kg}$ a.i./ha and mancozeb at $1.50 \mathrm{~kg}$ a.i./ha significantly reduced ergot incidence, whereas all except azoxystrobin at $0.062 \mathrm{~kg}$ a.i./ha significantly reduced ergot severity, compared with the control treatment (Table 4). Only the higher triadimenol rate, the propiconazole, the acibenzolar-S-methyl + mancozeb, and the higher rate of acibenzolar-S-methyl treatments were significantly better than all other treatments for both per cent incidence and per cent severity.

Trials 3 and 4. In trial 3, all four spray treatments (triadimenol at 0.063 or $0.125 \mathrm{~kg}$ a.i./ha sprayed four times, and acibenzolar-S-methyl at $0.05 \mathrm{~kg}$ a.i./ha sprayed once (with or without four additional sprays of mancozeb) significantly reduced ergot severity compared with the control (36.8\% severity). Although there were no statistically significant differences between the spray treatments, the two triadimenol treatments were the best $(0.1$ and $1.4 \%$ severity, respectively), followed by acibenzolar-S-methyl + mancozeb $(2.1 \%)$ and the single acibenzolar spray $(13.1 \%)$. In trial 4 , the ergot severity values of all the fungicides were significantly lower than the unsprayed treatment $(84.3 \%)$, with the triadimenol spray at $0.125 \mathrm{~kg}$ a.i./ha being significantly better $(11.1 \%)$ than the other treatments, fenhexamid at 0.50 or $0.25 \mathrm{~kg}$ a.i./ha $(76.3 \%$ and $80.4 \%$, respectively) and JAU 6476 at 0.25 or $0.125 \mathrm{~kg}$ a.i./ha (24.3\% and $35.9 \%$, respectively).

\section{Interval/timing}

Interval trial 1. All spray interval treatments using tebuconazole had significantly lower values of ergot incidence, but only the 2- and 4-day intervals significantly reduced severity compared with the unsprayed treatment (Table 5). There was a trend for increasing ergot incidence and severity as the interval between sprays increased. The 2-day interval provided significantly better control of ergot than the other intervals, irrespective of the parameter.

Interval trial 2. Only the two triadimenol treatments (0.125 and $0.063 \mathrm{~kg}$ a.i./ha) and the higher propiconazole treatment $(0.25 \mathrm{~kg}$ a.i./ha) had significantly lower values of both per cent incidence and severity than the unsprayed treatment (Table 6). The best acibenzolar-S-methyl treatment (four sprays at $0.025 \mathrm{~kg}$ a.i./ha) was as effective as the lower rate of triadimenol $(0.063 \mathrm{~kg}$ a.i./ha) and the higher rate of propiconazole for both per cent incidence and severity. The 
Table 3. Efficacies of fungicides for control of Claviceps africana, efficacy trial 1

\begin{tabular}{lccccc}
\hline Fungicide & $\begin{array}{c}\text { Fungicide rate } \\
\text { (kg a.i./ha) }\end{array}$ & \multicolumn{2}{c}{ Incidence $^{\mathrm{A}}$} & \multicolumn{2}{c}{ Severity $^{\mathrm{B}}$} \\
& Rating $1^{\mathrm{C}}$ & Rating 2 $^{\mathrm{C}}$ & Rating 1 & Rating 2 \\
\hline Triadimenol & 0.25 & $0 \mathrm{a}^{\mathrm{D}}$ & $0 \mathrm{a}$ & $0 \mathrm{a}$ & 0 \\
Tebuconazole & 0.25 & $1.2 \mathrm{ab}$ & $2.3 \mathrm{a}$ & $0.1 \mathrm{a}$ & $<1$ \\
Triadimenol & 0.125 & $4.6 \mathrm{ab}$ & $3.1 \mathrm{a}$ & $0.2 \mathrm{a}$ & $<1$ \\
Mancozeb & 1.50 & $18.6 \mathrm{bc}$ & $58.9 \mathrm{~b}$ & $2.6 \mathrm{a}$ & $<1-10$ \\
Fluazinam & 0.50 & $23.3 \mathrm{c}$ & $52.3 \mathrm{~b}$ & $1.5 \mathrm{a}$ & $<1-5$ \\
Benomyl & 1.00 & $34.7 \mathrm{~cd}$ & $58.9 \mathrm{~b}$ & $0.9 \mathrm{a}$ & $<1-10$ \\
Fluazinam & 0.25 & $46.7 \mathrm{de}$ & $89.4 \mathrm{c}$ & $5.6 \mathrm{~b}$ & $<1-70$ \\
Procymidone & 0.25 & $57.8 \mathrm{ef}$ & $96.9 \mathrm{c}$ & $5.0 \mathrm{~b}$ & $10-70$ \\
Triademorph & 0.30 & $60.4 \mathrm{ef}$ & $88.1 \mathrm{c}$ & $7.0 \mathrm{~cd}$ & $10-70$ \\
Procymidone & 0.125 & $69.4 \mathrm{f}$ & $97.9 \mathrm{c}$ & $8.3 \mathrm{~d}$ & $20-70$ \\
Unsprayed & & $58.0 \mathrm{ef}$ & $96.5 \mathrm{c}$ & $7.4 \mathrm{c}$ & $10-80$ \\
\hline
\end{tabular}

${ }^{\mathrm{A}}$ Per cent infected panicles/row. ${ }^{\mathrm{B}}$ Per cent infected spikelets/panicle.

${ }^{C}$ Rating dates 29 May 1997 (rating 1) and 6 June 1997 (rating 2).

DValues in each column with different letters are statistically different at $P<0.05$.

Table 4. Efficacies of fungicides and compounds for control of Claviceps africana, efficacy trial 2

\begin{tabular}{lccc}
\hline Fungicide or compound & $\begin{array}{c}\text { Fungicide rate } \\
\text { (kg a.i./ha) }\end{array}$ & Incidence $^{\mathrm{A}}$ & Severity $^{\mathrm{B}}$ \\
\hline Triadimenol & 0.125 & $55.2 \mathrm{a}$ & $0.5 \mathrm{a}$ \\
Propiconazole & 0.25 & $65.6 \mathrm{ab}$ & $0.9 \mathrm{ab}$ \\
Acibenzolar-S-methyl + mancozeb & $0.05+1.5$ & $47.2 \mathrm{a}$ & $0.7 \mathrm{a}$ \\
Acibenzolar-S-methyl & 0.05 & $60.3 \mathrm{ab}$ & $1.4 \mathrm{abc}$ \\
Triadimenol & 0.063 & $76.5 \mathrm{~b}$ & $1.6 \mathrm{abc}$ \\
Acibenzolar-S-methyl & 0.025 & $76.5 \mathrm{~b}$ & $1.4 \mathrm{abc}$ \\
Tebuconazole & 0.25 & $79.5 \mathrm{bc}$ & $2.0 \mathrm{bc}$ \\
Mancozeb & 1.50 & $84.6 \mathrm{bc}$ & $1.8 \mathrm{bc}$ \\
Propiconazole & 0.125 & $97.4 \mathrm{c}$ & $2.4 \mathrm{~cd}$ \\
Azoxystrobin & 0.125 & $93.5 \mathrm{~b}$ & $3.6 \mathrm{de}$ \\
Azoxystrobin & 0.063 & $97.7 \mathrm{c}$ & $3.2 \mathrm{~d}$ \\
Unsprayed & & $100 \mathrm{c}$ & $4.8 \mathrm{e}$ \\
\hline
\end{tabular}

${ }^{\text {A }}$ Per cent infected panicles/row.

${ }^{\mathrm{B}} 0=0 \%$ infected spikelets/panicle, $10=100 \%$ infected spikelets/panicle.

${ }^{\mathrm{C}}$ Values in each column with different letters are statistically different at $P<0.05$.

other acibenzolar-S-methyl treatments were not significantly different from each other or from the unsprayed treatment for either parameter.

Timing trial. Acibenzolar-S-methyl significantly reduced ergot severity, compared with the unsprayed control only when applied 4 days before, or immediately after, inoculation. No ergot developed when the compound was applied 4 days before inoculation (Fig. 1). For triadimenol, a significant reduction in ergot severity occurred when it was applied 7 or 4 days before, immediately after, and 2 days after, inoculation. The lowest ergot severity occurred when the fungicide was applied 7 days before, or immediately after, inoculation (Fig. 1).

\section{Spray application}

Trial 1. In this trial, triadimenol significantly reduced ergot severity irrespective of the nozzle type and number of passes (Fig. 2). There were no significant differences in severity between the top four treatments, three of which were the flat fans, TJ60 and TX11001VB (single and double pass). The single pass with the hollow cone TX4 nozzles, and the double pass with the TX2 nozzles were the worst combinations. The TX11001VB single and double pass and the single pass TX4 nozzle treatments provided significantly better coverage $(6.5,7.2,7.1$, respectively) than the other three treatments (range 2.4-2.7).

Trial 2. All nozzles significantly reduced ergot severity compared with the unsprayed treatment, with the flat fan XR $80^{\circ}-01$ nozzles at both pressures being significantly better than the hollow cone $30 \mathrm{H}-\mathrm{CX} 4$ nozzles (Table 7). The $\mathrm{XR} 80^{\circ}-01$ flat fan nozzles operated at either $500 \mathrm{kPa}$ or $700 \mathrm{kPa}$ provided significantly greater deposition on panicles and on the pipe cleaners than the hollow cone nozzles. There were no significant differences for any parameter between the DG80 815 flat fan nozzles and the hollow cone nozzles.

Trial 3. All treatments significantly reduced the incidence and severity of ergot compared with the unsprayed 
Table 5. Effect of spraying interval with tebuconazole for control of Claviceps africana, interval trial 1

\begin{tabular}{lcc}
\hline Spray interval & Incidence $^{\mathrm{A}}$ & Severity $^{\mathrm{B}}$ \\
\hline 2 days & $2.1 \mathrm{a}^{\mathrm{C}}$ & $0.9 \mathrm{a}$ \\
4 days & $8.6 \mathrm{~b}$ & $1.7 \mathrm{~b}$ \\
6 days & $24.3 \mathrm{~d}$ & $2.3 \mathrm{bd}$ \\
8 days & $17.6 \mathrm{c}$ & $2.6 \mathrm{~cd}$ \\
Unsprayed & $40.8 \mathrm{e}$ & $2.6 \mathrm{~cd}$ \\
\hline
\end{tabular}

${ }^{\mathrm{A}} \mathrm{Per}$ cent infected panicles/row.

${ }^{\mathrm{B}} 0=0 \%$ infected spikelets/panicle, $10=100 \%$ infected spikelets $/$ panicle.

${ }^{\mathrm{C}}$ Values in each column with different letters are statistically different at $P<0.05$.

treatment (Table 8). The two flat fan treatments (four sprays of either 0.25 or $0.125 \mathrm{~kg}$ a.i./ha through three $11001 \mathrm{VB}$ nozzles) were significantly better than all other fungicide treatments for per cent incidence. For severity, these two treatments and the four applications through the two TX2 hollow cone nozzles were significantly better than the remainder, there being no significant differences between them. The single application through the hollow cone nozzles was the least effective treatment.

Trials 4 and 5. The mean value for per cent severity after the aerial application of triadimenol at $0.125 \mathrm{~kg}$ a.i./ha $[0.05 \% \pm 0.0005 \%$ (95\% confidence limit) $]$ was statistically significantly less $(P<0.05)$ than the corresponding value $[11.56 \% \pm 0.025 \% \quad(95 \%$ confidence limit $)]$ for the unsprayed treatment, using Student's ' $t$ ' test. In the equivalent ground rig trial, the mean values for ergot severity for both the $0.25 \mathrm{~kg}$ a.i./ha rate $(0 \%)$ and the $0.125 \mathrm{~kg}$ a.i./ha rate $(0.02 \%)$ were significantly less $(P<0.001)$ than the unsprayed control treatment $(6.40 \%)$.

\section{Discussion}

The three triazole (DMI) fungicides, triadimenol at $0.125 \mathrm{~kg}$ a.i. and $0.25 \mathrm{~kg}$ a.i./ha, and both tebuconazole and propiconazole at $0.25 \mathrm{~kg}$ a.i./ha, were the most effective treatments in our trials. Mena et al. (1998) found that propiconazole at $0.25 \mathrm{~kg}$ a.i./ha was the most effective treatment that they tested, while Pinto et al. (1999) reported that triadimenol at $0.0625,0.125$ and $0.025 \mathrm{~kg}$ a.i./ha provided better control $(<1 \%$ severity) than either tebuconazole or propiconazole at the same rates. In glasshouse trials, Odvody (2001) demonstrated complete control of $C$. africana with triademefon, and $6 \%$ severity with propiconazole when both were applied to flowering panicles just after inoculation. In the United States, propiconazole (as Tilt 250EC) has been registered for control of $C$. africana at a maximum rate of $0.133 \mathrm{lb}$ a.i./ac $(\cong 0.1236$ $\mathrm{kg}$ a.i./ha) per application, but no more than $0.3375 \mathrm{lb}$ a.i./ac

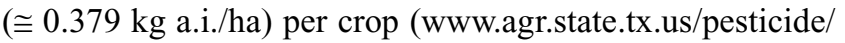
exemptions/pes_tilt01.htm), while in Australia an application for the registration of triadimenol at $0.125 \mathrm{~kg}$ a.i./ha is in progress.

Recent research using molecular techniques suggests that isolates of $C$. africana from India are very closely related to those from Australia, while African and American isolates are very similar (Pazoutova et al. 2000; Tooley et al. 2002). It is apparent that isolates from these two groups react similarly to the triazole fungicides because the results of trials in Australia (current study), Venezuela (Mena et al. 1998), Brazil (Pinto et al. 1999) and Africa (McLaren 1994) are similar.

Fungicides belonging to the other groups which we assessed were relatively ineffective. Mena et al. (1998) and Pinto et al. (1999) also found that the benzimidazole, benomyl and the diothiocarbamate, mancozeb, were not as

Table 6. Effect of spray intervals of acibenzolar-S-methyl for control of Claviceps africana, interval trial 2

\begin{tabular}{lcccc}
\hline Fungicide & $\begin{array}{c}\text { Fungicide rate } \\
\text { (kg a.i./ha) }\end{array}$ & No. of sprays & Incidence $^{\mathrm{A}}$ & Severity $^{\mathrm{B}}$ \\
\hline Triadimenol & 0.125 & 4 & $43.1 \mathrm{a}^{\mathrm{C}}$ & $0.5 \mathrm{a}$ \\
Propiconazole & 0.25 & 4 & $78.0 \mathrm{bc}$ & $1.1 \mathrm{ab}$ \\
Triadimenol & 0.063 & 4 & $69.6 \mathrm{~b}$ & $1.4 \mathrm{ab}$ \\
Acibenzolar-S-methyl & 0.05 & 4 & $79.2 \mathrm{bcd}$ & $1.5 \mathrm{bc}$ \\
Tebuconazole & 0.25 & 4 & $95.2 \mathrm{~cd}$ & $2.0 \mathrm{bcd}$ \\
Propiconazole & 0.125 & 4 & $97.4 \mathrm{~cd}$ & $2.4 \mathrm{cde}$ \\
Acibenzolar-S-methyl & 0.05 & 4 & $91.5 \mathrm{~cd}$ & $2.5 \mathrm{de}$ \\
Acibenzolar-S-methyl & 0.025 & 2 & $99.3 \mathrm{~d}$ & $3.6 \mathrm{de}$ \\
Acibenzolar-S-methyl & 0.05 & 2 & $100 \mathrm{~d}$ & $3.3 \mathrm{de}$ \\
Acibenzolar-S-methyl & 0.025 & 1 & $100 \mathrm{~d}$ & $3.5 \mathrm{de}$ \\
Acibenzolar-S-methyl & 0.05 & & $100 \mathrm{~d}$ & $3.7 \mathrm{de}$ \\
Unsprayed & & & $5.4 \mathrm{e}$ \\
\hline
\end{tabular}

${ }^{\mathrm{A}}$ Per cent infected panicles/row.

${ }^{\mathrm{B}} 0=0 \%$ infected spikelets/panicle, $10=100 \%$ infected spikelets/panicle

${ }^{\mathrm{C}}$ Values in each column with different letters are statistically different at $P<0.05$. 


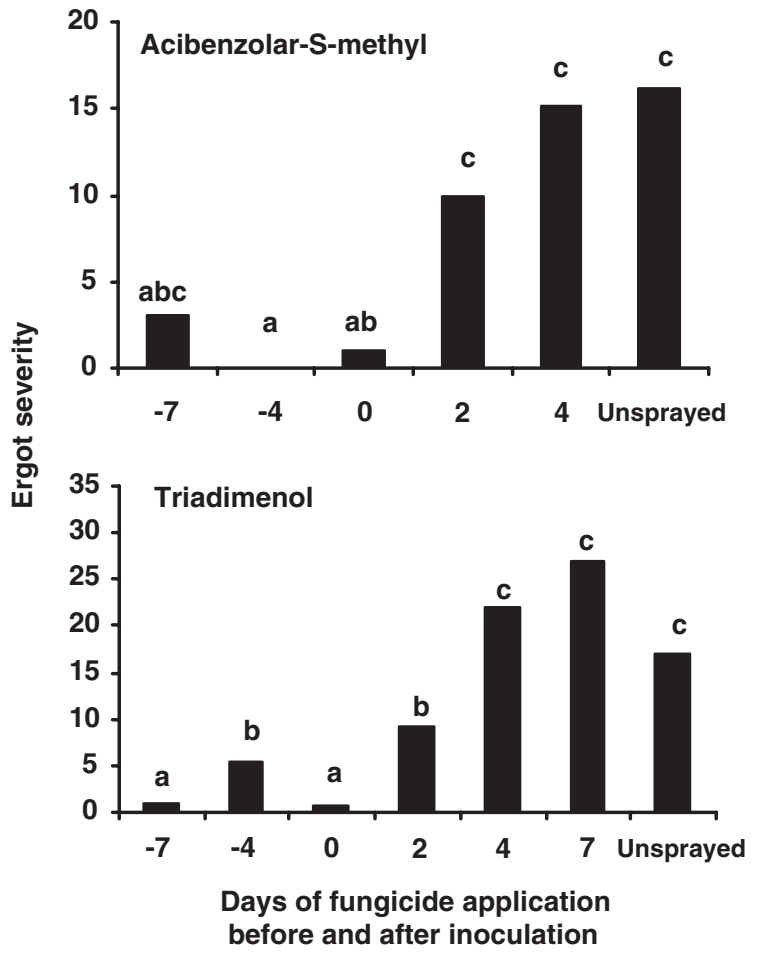

Fig 1. Effect of time of spraying of acibenzolar-S-methyl at 0.05 $\mathrm{kg}$ a.i./ha and triadimenol at $0.125 \mathrm{~kg}$ a.i./ha on ergot severity in a glasshouse trial. Different letters on bars represent significant differences in ergot severity values $(P<0.05)$.

effective as the triazoles which they tested. Earlier reports of high efficacy of fungicides belonging to these groups (Laksmanan and Mohan 1988; McLaren 1994; Frederickson and Leuschner 1997) may have been a reflection of the low ergot potential (sensu McLaren and Flett 1998) experienced during these trials.

Multiple applications of the P1 host plant defence inducer [also called Systemic Acquired Resistance inducer (Ryals et al. 1992)] acibenzolar-S-methyl at $0.05 \mathrm{~kg}$ a.i./ha were found to be relatively effective in reducing ergot incidence in our trials. In the glasshouse trial, acibenzolar-S-methyl was most effective when applied 4 days before inoculation with a

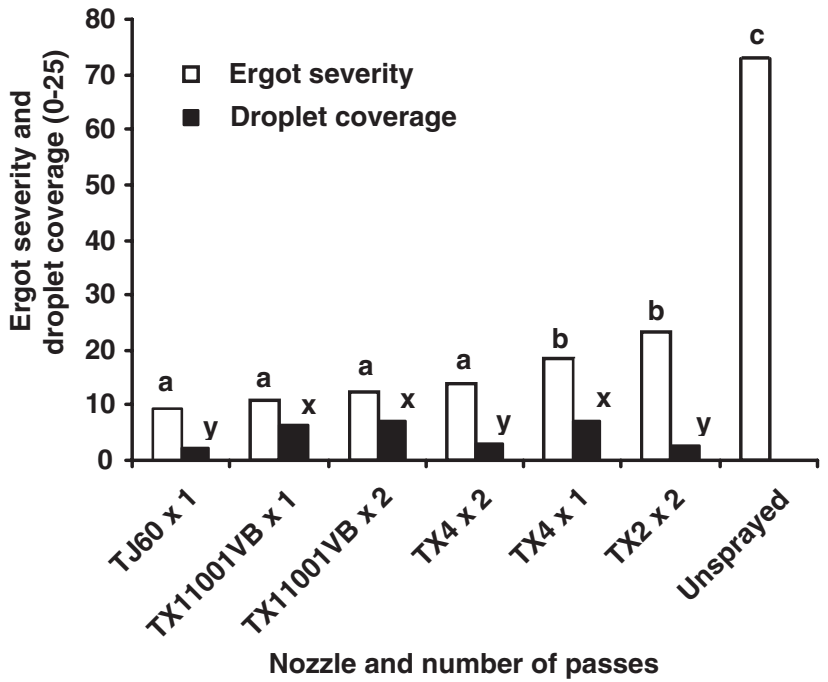

Fig. 2. Effect of nozzle type on ergot severity and droplet coverage in application trial 2. Triadimenol was applied at $0.10 \mathrm{~kg}$ a.i./300 L water/ha, with the addition of Helios at $30 \mathrm{~g}$ a.i./ha. Different letters on bars represent significant differences in ergot severity values, and in droplet coverage values $(P<0.05)$.

conidial suspension of C. africana. Siegrist et al. (1997) also reported that the compound had to be applied at least 4 days before inoculation to ensure protection against a range of fungal pathogens. It is likely that acibenzolar-S-methyl induces a systemic response in the gynoecia leading to an inhibition of either conidium germination or subsequent hyphal growth of $C$. africana. The systemic activity of the compound in individual panicles appears limited because there was a positive correlation between the number of applications and the reduction in ergot severity.

A single application of acibenzolar-S-methyl applied at first anthesis was less effective than multiple applications, but when combined with follow-up sprays of mancozeb at $1.5 \mathrm{~kg}$ a.i./ha the combination reduced disease severity to a value not significantly different from that of triadimenol at $0.125 \mathrm{~kg}$ a.i./ha (efficacy trial 2). Multiple applications of mancozeb alone were not as effective as the

Table 7. Effect of nozzle type and pressure on efficacy of triadimenol for control of Claviceps africana, application trial 2

\begin{tabular}{|c|c|c|c|c|c|}
\hline \multirow{3}{*}{$\begin{array}{l}\text { Nozzle and } \\
\text { pressure }(\mathrm{kPa})\end{array}$} & \multirow[t]{3}{*}{ Nozzle type } & \multirow[t]{3}{*}{ Severity ${ }^{\mathrm{A}}$} & \multicolumn{3}{|c|}{ Deposition } \\
\hline & & & \multirow[t]{2}{*}{ Panicles $^{\mathrm{B}}$} & \multicolumn{2}{|c|}{ Pipe cleaners ${ }^{\mathrm{C}}$} \\
\hline & & & & Row & $90^{\circ}$ to row \\
\hline XR $80^{\circ}-01,500$ & Flat fan & $5.6 \mathrm{a}^{\mathrm{D}}$ & $24.9 \mathrm{a}$ & $331.0 \mathrm{a}$ & $237.3 \mathrm{a}$ \\
\hline XR $80^{\circ}-01,700$ & Flat fan & $5.8 \mathrm{a}$ & $25.5 \mathrm{a}$ & $316.2 \mathrm{a}$ & $228.9 \mathrm{a}$ \\
\hline DG $80^{\circ}-015,500$ & Flat fan & $7.6 \mathrm{ab}$ & $20.5 \mathrm{ab}$ & $240.7 \mathrm{ab}$ & $180.7 \mathrm{ab}$ \\
\hline $30 \mathrm{H}-\mathrm{CX} 4,500$ & Hollow cone & $10.2 \mathrm{~b}$ & $12.5 \mathrm{~b}$ & $128.0 \mathrm{bc}$ & $141.7 \mathrm{bc}$ \\
\hline Unsprayed & & $18.0 \mathrm{c}$ & $2.8 \mathrm{c}$ & $40.8 \mathrm{c}$ & $39.0 \mathrm{c}$ \\
\hline
\end{tabular}

${ }^{\mathrm{A}}$ Per cent infected spikelets/panicle. ${ }^{\mathrm{B}} \mu \mathrm{g} / \mathrm{L}$ of Helios/30 $\mathrm{mL}$ solvent/g panicle. ${ }^{\mathrm{C}} \mu \mathrm{g} / \mathrm{L}$ of Helios/10 mL solvent/g panicle. DValues in each column with different letters are statistically different at $P<0.05$. 
Table 8. Efficacies of nozzles for control of Claviceps africana using triadimenol, application trial 3

\begin{tabular}{lcccc}
\hline Nozzles & No. of sprays & $\begin{array}{c}\text { Fungicide rate } \\
(\text { kg a.i./ha) }\end{array}$ & Incidence $^{\mathrm{A}}$ & Severity $^{\mathrm{B}}$ \\
\hline $3 \times 11001$ VB flat fans & 4 & 0.25 & $0.0 \mathrm{a}^{\mathrm{C}}$ & $0.0 \mathrm{a}$ \\
$3 \times 11001$ VB flat fans & 4 & 0.125 & $1.3 \mathrm{a}$ & $0.0 \mathrm{a}$ \\
$2 \times \mathrm{TX} 2$ hollow cones & 4 & 0.125 & $7.5 \mathrm{~b}$ & $0.0 \mathrm{a}$ \\
$2 \times \mathrm{TX} 2$ hollow cones & 2 & 0.125 & $26.3 \mathrm{c}$ & $0.2 \mathrm{~b}$ \\
$2 \times \mathrm{TX} 2$ hollow cones & 1 & 0.125 & $46.3 \mathrm{~d}$ & $0.3 \mathrm{c}$ \\
Unsprayed & \multicolumn{5}{l}{$17.8 \mathrm{~d}$} \\
\hline APer cent infected panicles/row. & ${ }^{\mathrm{B}}$ Per cent infected spikelets/panicle. \\
Incidence and severity values with different letters are statistically different at $P<0.05$ and \\
$P<0.01$, respectively.
\end{tabular}

acibenzolar-S-methyl + mancozeb combination (efficacy trial 2), suggesting a possible synergistic effect. Resistance to DMI fungicides has been reported for a range of pathogens overseas (Blatter et al. 1998; Leroux et al. 2000; Karaoglanidis et al. 2002) and in Australia (O'Brien 1994; Wallwork 1995), so it is possible that isolates of C. africana resistant to DMI could develop in Australia with repeated applications of triadimenol. A combination of acibenzolar-S-methyl and mancozeb offers a cost-effective alternative to the triazoles, should such resistant isolates develop.

Our trials and those of other researchers (Anahosaur 1980; Lakshmanan et al. 1986; Lakshmanan and Mohan 1988; McLaren 1994; Mena et al. 1998) indicate that multiple applications of fungicides are required for effective control of C. africana. McLaren (1994) surmised that DMI fungicides had limited systemic activity and little or no eradicant (residual) capacity in flowering panicles of S. bicolor. Gisi et al. (1986) report that the DMIs, including triadimenol, move acropetally in the transpiration stream and that triadimenol has a 4-8 day preventative activity and some curative activity against pathogens causing rust or powdery mildew. Our glasshouse timing trial showed that in flowering panicles, triadimenol had little or no curative activity $(<2$ days) but that it possessed some residual and preventative activity lasting at least 7 days. However, in the field timing trial using tebuconazole (interval trial 1), there was a positive relationship between spray interval and ergot severity, which suggests that the fungicide's residual activity is $<4$ days and that its systemic activity within a panicle is limited. Our findings support McLaren's (1994) conclusions on the activity and movement of the DMI fungicides in sorghum panicles and indicate that they seem to act as contact fungicides which must be applied directly to the stigmas for maximum efficacy.

Control of plant pathogens with fungicides requires the use of an efficacious fungicide that is applied at the correct time and often on a number of occasions and by a suitable method of application. C. africana is no exception. Details of nozzle type, pressure and water rate/ha are, for the most part, lacking in previous studies on the efficacy of fungicides to $C$. africana. Our studies have demonstrated that DMI fungicides are more efficacious when applied through flat fan nozzles than through hollow cone nozzles. Possible explanations for this finding are that: (i) droplets leaving a cone nozzle have less momentum than those leaving a flat fan nozzle due to the swirling nature of the spray as it leaves the nozzle, hence they have less impact when they reach the panicles; (ii) cone nozzles produce a higher proportion of very fine droplets $(<100 \mu \mathrm{m}$ diameter $)$, which are susceptible to evaporation and drift; and (iii) droplets leaving the fan nozzles have greater exit velocities and reach the panicles sooner than those from hollow cone nozzles, making them less prone to drift and evaporation. In many situations, such as following rain periods when infection is likely to occur (Ryley et al. 2003a), aerial application is the preferred option. The results of our trials suggest that applications of triadimenol as small droplets in low water volumes $(50 \mathrm{~L} / \mathrm{ha})$ are as effective in reducing ergot severity as applications using larger droplets in higher water volumes ( $>100 \mathrm{~L} / \mathrm{ha}$ ), thereby making aerial application a viable option.

In conclusion, we have demonstrated that triadimenol is efficacious in minimising infection of $S$. bicolor by C. africana. We have shown that the fungicide must be applied at anthesis and then at 4- to 5-day intervals during flowering. In ground rig applications, efficacy can be improved by using flat fan nozzles instead of hollow cone nozzles; aerial application is also effective if appropriate nozzles, pressure and water rate are used. These findings can be applied to hybrid seed production blocks and breeder's nurseries not only in Australia but also overseas.

\section{Acknowledgements}

The authors thank the management and staff of Pacific Seeds and Pioneer Australia for their contribution to these findings through their donated resources of land, machinery and labour. Most of this research was funded by the Grains Research \& Development Corporation. 


\section{References}

Anahosaur KH (1980) Chemical control of ergot of sorghum. Indian Phytopathology 32, 487-489.

Bandyopadhyay R, Frederickson DE, McLaren NW, Odvody GN (1996) Ergot - a global threat to sorghum. International Sorghum and Millets Newsletter 37, 1-32.

Bandyopadhyay R, Frederickson DE, McLaren NW, Odvody GN, Ryley MJ (1998) Ergot: a new disease threat to sorghum in the Americas and Australia. Plant Disease 82, 356-367.

Bhuiyan SA, Ryley MJ, Galea VJ, Tay D, Lisle AT (2002) Survival of conidia of sorghum ergot (caused by Claviceps africana) on panicles, seed and soil in Australia. Australasian Plant Pathology 31, 137-141.

Blatter RHE, Brown JKM, Wolfe MS (1998) Genetic control of the resistance of Erysiphe graminis f.sp. hordei to five triazole fungicides. Plant Pathology 47, 570-579.

Dahlberg J, Bandyopadhyay R, Rooney B, Odvody G, Madera-Torres P (2001) Evaluation of sorghum germplasm used in US breeding programmes for sources of sugary disease resistance. Plant Pathology 50, 681-689.

Doggett HH (1988) 'Sorghum.' (Longman Scientific \& Technical: Harlow, England)

Frederickson DE, Leuschner K (1997) Potential use of benomyl for control of ergot (Claviceps africana) in sorghum A-lines in Zimbabwe. Plant Disease 81, 761-765.

Frederickson DE, Mantle PG, de Milliano WAJ (1991) Claviceps africana sp. nov., the distinctive ergot pathogen of sorghum in Africa. Mycological Research 95, 1101-1107.

Frederickson DE, Mantle PG, de Milliano WAJ (1993) Windborne spread of ergot disease (Claviceps africana) in sorghum A-lines in Zimbabwe. Plant Pathology 42, 368-377.

Frederickson DE, Odvody GN (1999) 'Distinguishing sphacelia and sclerotia of Claviceps africana in seed.' Publication L-5315, The Texas A\&M University System. 5 pp.

Gisi U, Rimbach E, Binder H, Altwegg P, Hugelshofer U (1986) Biological profile of SAN $619 \mathrm{~F}$ and related EBI-fungicides. In ' 1986 British crop protection conference. Pests and diseases'. Vol. 2. pp. 857-864. (British Crop Protection Council: Thornton Heath, UK)

Karaoglanidis GS, Ioannidis PM, Thanassoulopoulos C (2002) Changes in sensitivity of Cercospora beticola populations to sterol-demethylation-inhibiting fungicides during a 4-year period in northern Greece. Plant Pathology 51, 55-62

Lakshmanan P, Chandrasekaran A, Palanisamy S (1986) Chemical control of sugary disease of sorghum. Sorghum Newsletter 29, 81.

Lakshmanan P, Mohan S (1988) Studies of the effect of various fungicides on Sphacelia sorghi. Pesticides 22, 27.

Leroux P, Chapeland F, Arnold A, Gredt M (2000) New cases of negative cross-resistance between fungicides, including sterol biosynthesis inhibitors. Journal of General Plant Pathology 66, $75-81$.

McLaren NW (1994) Efficacy of systemic fungicides and timing of preventive sprays in the control of sugary disease of grain sorghum (Sorghum bicolor). South African Journal of Plants and Soil 11, 30-33.

McLaren NW, Flett BC (1998) Use of weather variables to quantify sorghum ergot potential in South Africa. Plant Disease 82, 26-29.
McLaren NW, Wehner FC (1990) Relationship between climatic variables during early flowering of sorghum and the incidence of sugary disease caused by Sphacelia sorghi. Journal of Phytopathology 130, 82-88.

McLaren NW, Wehner FC (1992) Pre-flowering low temperature predisposition of sorghum to sugary disease (Claviceps africana). Journal of Phytopathology 135, 328-334.

Mena H, Feunmayor F, Tejera J, Georges E, Jimenez R (1998) Chemical control of sorghum ergot (Claviceps africana) in the field. International Sorghum and Millets Newsletter 39, 105-106.

O'Brien R (1994) Fungicide resistance in populations of cucurbit powdery mildew (Sphaerotheca fuliginea). New Zealand Journal of Crop and Horticultural Science 22, 145-149.

Odvody G (2001) Development of plant disease protection systems for millet and sorghum in semi-arid Southern Africa. In 'INTSORMIL 2001 annual report'. INTSORMIL publication 01-5. (Eds JM Yohe, T Crawford, J Frederick, D Stoner) pp. 30-37. (INTSORMIL: Lincoln, Nebraska, USA)

Pazoutova S, Bandyopadhyay R, Frederickson DE, Mantle PG, Frederiksen RA (2000) Relations among sorghum ergot isolates from the Americas, Africa, India and Australia. Plant Disease 84, 437-442.

Pinto NFJ de Almeida, Ferreira A da Silva, Casela CR (1999) Chemical control of sugary disease of sorghum (Claviceps africana). In 'Proceedings of the global conference on ergot of sorghum'. INTSORMIL Publication 99-1. (Eds CR Casela, JA Dahlberg) pp. 158-160. (INTSORMIL: Lincoln, Nebraska, USA)

Ryals J, Ward E, Ahl-Goy PA, Metraux JP (1992) Systemic acquired resistance: an inducible defence mechanism in plants. In 'The biochemistry and molecular biology of inducible enzymes and proteins in higher plants'. (Ed. JL Wray) pp. 205-229. (Cambridge University Press: Cambridge, England)

Ryley MJ, Herde DJ, Bhuiyan SA, Henzell RG, Jordan DR (2003a) An overview of the biology of sorghum ergot. In 'Sorghum and millets diseases 2000'. (Ed. JF Leslie) pp. 141-150. (Iowa State University Press: Ames, Iowa, USA)

Ryley MJ, Persley DM, Jordan DR, Henzell RG (2003b) Status of sorghum and pearl millet diseases in Australia. In 'Sorghum and millets diseases 2000'. (Ed. JF Leslie) pp. 441-450. (Iowa State University Press: Ames, Iowa, USA)

Siegrist J, Glenewinkel D, Kolle C, Schmidke M (1997) Chemically induced resistance in green bean against bacterial and fungal pathogens. Journal of Plant Diseases and Protection 104, 599-610.

Tooley PW, Goley ED, Carras MM, O'Neill NR (2002) AFLP comparisons among Claviceps africana isolates from the United States, Mexico, Africa, Australia, India and Japan. Plant Disease 86, 1247-1252.

Tsukiboshi T, Shimanuki T, Uematsu T (1999) Claviceps sorghicola sp. nov., a destructive ergot pathogen of sorghum in Japan. Mycological Research 103, 1403-1408.

Wallwork H (1995) Barley leaf blights in Australia and New Zealand: historical perspective and current situation. Rachis 14, 75-81.

Received 29 November 2002, accepted 25 February 2003 